\title{
FAKTOR PENYEBAB KECEMASAN ISTRI MENGHADAPI SUAMI YANG DIRAWAT INAP DI RSUD DR. PIRNGADI MEDAN
}

\author{
Rudi Marhujar ${ }^{1^{*}}$, Badiran ${ }^{2}$, Jamaluddin ${ }^{3}$ \\ Program Studi Kesehatan Masyarakat, Institut Kesehatan Helvetia \\ *email: rudi_marhuzar@yahoo.com
}

\begin{abstract}
ABSTRAK
Kecemasan merupakan reaksi normal terhadap situasi yang sangat menekan kehidupan seseorang. Kecemasan bisa muncul sendiri atau bergabung dengan gejala-gejala lain dari berbagai gangguan emosi. Adapun tujuan dalam penelitian ini adalah untuk menganalisis faktor penyebab kecemasan istri menghadapi suami yang di rawat inap di RSUD Dr. Pirngadi Medan. Jenis penelitian ini merupakan survei analitik dengan rancangan cross sectional study. Sampel penelitian ada sebanyak 88 orang yang diperoleh dengan menggunakan rumus slovin. Untuk menganalisis data tersebut digunakan uji regresi logistik. Berdasarkan hasil penelitian diketahui bahwa faktor biaya berobat, faktor beresiko kehilangan orang yang dicintai, faktor kesembuhan, faktor siapa yang menjaga, faktor urusan rumah tangga, faktor ancaman nafkah keluarga, dan faktor lama rawat inap berpengaruh terhadap kecemasan istri menghadapi suami yang dirawat inap di RSUD DR. Pirngadi Medan dan faktor yang paling berhubungan adalah faktor beresiko kehilangan orang yang dicintai. Berdasarkan hasil penelitian, maka disarankan agar istri dapat meningkatkan keimanan supaya bersabar menghadapi suami yang dirawat inap dan dapat lebihkan meningkatkan kepercayaan atau keyakinan terhadap pelayanan rumah sakit untuk kesembuhan suami yang dirawat.
\end{abstract}

Kata Kunci : Istri, Kecemasan, Faktor-Faktor

\section{ABSTRACT}

Anxiety is a normal reaction to situations that are very stressful in a person's life. Anxiety can appear alone or combine with other symptoms of various emotional disorders. The purpose of this study was to analyze the factors that cause the wife's anxiety to face her husband who was hospitalized at Dr. Pirngadi Medan. This type of research is an analytic survey with a cross sectional study design. There were 88 research samples which were obtained using the Slovin formula. To analyze the data logistic regression test was used. Based on the results of the study note that the cost of treatment, factors at risk of losing loved ones, healing factors, factors that take care, household factors, family life threat factors, and length of stay factors affect the anxiety of the wife facing her husband who was hospitalized in hospitals DR. Pirngadi Medan and the most related factor is the risk of losing a loved one. Based on the results of the study, it is suggested that wives can increase their faith so that they can be patient in facing husbands who are hospitalized and can increase their trust or confidence in hospital services for the healing of hospitalized husbands.

Keywords: Wife, Anxiety, Factors

\section{PENDAHULUAN}

Suami merupakan individu yang sangat dibutuhkan oleh seorang istri, yang keduanya bersama dengan anak (kalau ada) membentuk suatu rumah tangga atau keluarga, hal tersebut disebabkan peranan suami sangat vital yaitu sebagai kepala atau pemimpin rumah tangga yang mana kehadirannya ditengah-tengah rumah tangga sangat dibutuhkan di dalam menjalani kehidupan sehari-hari. ${ }^{1}$

Peran suami dalam rumah tangga selain sebagai pengambil keputusan, juga merupakan pengelola keuangan keluarga dan bersama dengan istri mendidik anak. ${ }^{2}$ sehingga apabila sesuatu peristiwa yang tidak diharapkan terjadi pada suami, dapat menyebabkan dampak yang besar bagi keluarga khususnya istri seperti gangguan kesehatan pada fisik maupun psikisnya. ${ }^{3}$

Salah satu gangguan yang sering dialami oleh istri adalah gangguan psikis yaitu cemas. Kecemasan adalah sesuatu yang menimpa hampir setiap orang pada waktu tertentu dalam kehidupannya. Kecemasan merupakan reaksi normal terhadap situasi yang sangat menekan kehidupan seseorang. Kecemasan bisa muncul sendiri atau bergabung dengan gejala-gejala lain dari berbagai gangguan emosi.

Pada dasarnya, kecemasan merupakan hal wajar yang pernah dialami oleh setiap manusia. Kecemasan sudah dianggap sebagai bagian dari kehidupan sehari-hari. Kecemasan adalah suatu perasaan yang sifatnya umum, dimana seseorang merasa 
ketakutan atau kehilangan kepercayaan diri yang tidak jelas asal maupun wujudnya. ${ }^{5}$

Menurut WHO tahun 2017, gangguan kecemasan adalah salah satu gangguan mental yang umum dengan prevalensi seumur hidup yaitu 16\%-29\%. Dilaporkan bahwa perkiraan gangguan kecemasan pada dewasa muda di Amerika adalah sekitar $18,1 \%$ atau sekitar 42 juta orang hidup dengan gangguan kecemasan, seperti gangguan panik, gangguan obsesiv-kompulsif, gangguan stres pasca trauma, gangguan kecemasan umum dan fobia. Sedangkan gangguan kecemasan terkait jenis kelamin dilaporkan bahwa prevalensi gangguan kecemasan seumur hidup pada wanita sebesar $60 \%$ lebih tinggi dibandingkan pria. $^{6}$

Di Indonesia prevalensi terkait gangguan kecemasan menurut hasil Riset Kesehatan Dasar (Riskesdas) pada tahun 2013 menunjukkan bahwa sebesar $6 \%$ untuk usia 15 tahun ke atas atau sekitar 14 juta penduduk di Indonesia mengalami gangguan mental emosional yang ditunjukkan dengan gejala-gejala kecemasan dan depresi. Berdasarkan hasil penelitian tersebut diketahui bahwa setiap orang dapat mengalami kecemasan baik cemas ringan, sedang atau berat.

Cemas bisa terjadi pada siapa saja, termasuk juga pada istri yang memiliki suami yang sedang sakit dan dalam masa perawatan di ruang rawat inap di sebuah rumah sakit. Kecemasan istri ini salah satunya adalah bagaimana menjalankan perannya dan menghadapi suami yang sedang dirawat inap, dan bagaimana kondisi suaminya apakah dapat disembuhkan atau tidak. Kecemasan ini bisa muncul ketika istri dihadapkan pada kondisi perasaan yang tidak menentu berasal dari antisipasi terhadap adanya bahaya atau suatu ancaman ketika dihadapkan pada perubahan dan kebutuhan untuk melakukan tindakan yang berbeda, kecemasan istri tersebut dapat disebabkan oleh berbagai factor. $^{8}$

Kecemasan selalu melibatkan komponen psikis (afektif, kognitif, perilaku) dan biologis (somatik, neurofisiologis). Gejala somatik sangat bervariasi pada masing-masing individu, tetapi pada dasarnya merupakan manifestasi keterlibatan saraf otonom dan sistem visceral yaitu sistem urogenital (sering kencing atau sulit keing), sistem cardiovascular (tekanan darah tinggi, berkeringat dingin, sakit kepala, ), sisem gastrointestinal (diare, kembung, iritasi lambung,), sistem urogenital (sering kencing atau sulit kencing), sistem respiratori (nyeri dada, hidung tersumbat), sistem musculosceletal (kejang, nyeri otot, dan keluhan mirip rematik). Keluhan-keluhan di atas berhubungan dengan kecemasan seorang istri ketika menghadapi suami yang di rawat inap.

Kecemasan adalah kekhawatiran yang tidak jelas dan menyebar, yang berkaitan dengan perasaan yang tidak pasti dan tidak berdaya. keadaan emosi ini tidak memiliki objek yang spesifik. Istri yang mengalami kecemasan merupakan suatu pengalaman subjektif mengenai ketegangan mental yang menggelisahkan sebagai reaksi umum dan ketidakmampuan menghadapi masalah atau rasa aman.

Dalam suatu penelitian didapatkan bahwa stress tinggi mempunyai resiko kematian 40 kali lebih besar dibanding stress renda. ${ }^{9}$ Teori tersebut diatas tentang betapa pentingnya kehadiran seorang suami terhadap munculnya cemas atau pengurangan cemas istri telah dibuktikan dari salah satu penelitian yang dilakukan oleh Nasihah dan Hidayah tahun 2015 yang menemukan bahwa kecemasan ibu yang sedang melahirkan akan berkurang apabila suami hadir mendampinginya, meskipun suami tidak dapat berbuat apapun untuk menolong persalinan si istri. ${ }^{10}$

Kaplan dan Sadock menyatakan bahwa faktor yang memengaruhi kecemasan seseorang antara lain : usia, pengalaman di rumah sakit, konsep diri dan peran, status sosial ekonomi, komunikasi teraupetik, kondisi medis/diagnosis penyakit, tingkat pendidikan, akses informasi, dan proses adaptasi, tingkat sosial ekonomi,jenis tindakan medis,jenis tindakan pengobatan, komunikasi terapeutik. Ancaman terhadap integritas diri, meliputi ketidakmampuan fisiologis atau gangguan dalam melakukan aktifitas sehari-hari guna pemenuhan terhadap kebutuhan dasarnya serta adanya sesuatu yang dapat mengancam terhadap identitas diri, harga diri, kehilanga status atau peran diri, dan hubungan interpersonal. ${ }^{11}$

Berdasarkan hasil survei awal yang dilakukan di RSUD DR. Pirngadi Medan per Oktober tahun 2019 di dapatkan data sekunder yaitu jumlah pasien laki-laki dengan identitas menikah dan di rawat inap ada sebanyak 7.313 orang. Apabila di rata-ratakan jumlah pasien rawat inap selama sepuluh bulan, maka jumlah pasien adalah 731 pasien perbulan,

Dari 731 orang pasien tersebut, hampir seluruhnya di dampingi oleh istri selama di rawat inap di rumah sakit dan semua istri pasien mengaku cemas melihat suaminya di rawat inap. Kecemasan istri tersebut tentu saja dilatarbelakangi berbagai faktor, oleh sebab itu peneliti meminta 20 orang istri pasien agar 
bersedia dilakukan wawancara untuk mengetahui faktor apa saja yang membuat istri pasien menjadi cemas. Dari hasil wawancara, peneliti merangkum bahwa kecemasan istri pasien disebabkan oleh takut kehilangan orang yang dicintai, apakah suami dapat sembuh, biaya berobat, siapa yang mencari nafkah dan siapa yang mengurus rumah tangga apabila istri terus-terusan berada untuk menjaga suami. Berdasarkan paparan di atas, peneliti tertarik untuk meneliti "Faktor Penyebab Kecemasan Istri Menghadapi Suami Yang Dirawat Inapdi RSUD DR. Pirngadi Medan Tahun 2020"

\section{BAHAN DAN METODE}

Jenis penelitian ini merupakan survei analitik dengan rancangan cross sectional study. Penelitian dilakukan di rawat inap di RSUD Dr. Pirngadi Medan. Sampel penelitian ada sebanyak 88 orang yang diperoleh dengan menggunakan rumus slovin. Untuk menganalisis data tersebut digunakan uji regresi logistik.

\section{HASIL}

\section{Analisis Data Univariat}

Berdasarkan data yang diperoleh dari hasil penelitian dengan 88 responden dapat dilihat dalam tabel distribusi frekuensi sebagai berikut.

Tabel 1. Distribusi Responden di Ruang Rawat Inap RSUD Dr. Pirngadi Medan Tahun 2019

\begin{tabular}{lrr}
\hline Kelompok Umur (Tahun) & $\mathbf{n}$ & \% \\
\hline 21-25 Tahun & 3 & 3,40 \\
26-35 Tahun & 25 & 28,41 \\
36-45 Tahun & 31 & 35,23 \\
46-55 Tahun & 21 & 23,86 \\
56-65 Tahun & 8 & 9,10 \\
\hline Tingkat Pendidikan & $\mathbf{n}$ & $\%$ \\
\hline SMP & 19 & 21,59 \\
SMA & 37 & 42,04 \\
PT & 32 & 36,37 \\
\hline Pekerjaan & $\mathbf{n}$ & $\%$ \\
\hline Petani & 7 & 7,95 \\
Wiraswasta & 29 & 32,95 \\
PNS & 22 & 25,00 \\
Lain-lainnya & 30 & 34,10 \\
\hline Jumlah & $\mathbf{8 8}$ & $\mathbf{1 0 0}$ \\
\hline & &
\end{tabular}

Berdasarkan tabel di atas, diketahui bahwa dari 88 responden, sebagian besar responden berumur 36-45 tahun yaitu sebanyak 31 $(35,23 \%)$ responden, sedangkan responden lainnya berumur 21-25 tahun yaitu sebanyak 3 $(3,40 \%)$ responden, umur $26-35$ tahun sebanyak $25(28,41)$, umur 46-55 tahun sebanyak 21 $(23,86 \%)$, umur $56-65$ tahun $8 \quad(9,10 \%)$ responden.

Dari 88 responden diketahui bahwa sebagian besar responden merupakan tamatan SMA yaitu sebanyak 37 (42,04\%) responden, tamatan SMP sebanyak 19 $(21,59 \%)$ responden dan tamatan PT ada sebanyak 32 (36,37\%) responden. Dari 88 responden diketahui bahwa sebagian besar responden memiliki pekerjaan lain-lainnya yaitu sebanyak $30 \quad(34,10 \%)$ responden, responden lainnya memiliki pekerjaan Petani yaitu sebanyak $7(7,95 \%)$ responden, memiliki pekerjaan wiraswasta yaitu sebanyak 29 $(32,95 \%)$ responden, dan memiliki pekerjaan PNS yaitu sebanyak $22(2500 \%)$ responden

\section{Analisis Data Bivariat}

Untuk mengetahui faktor yang berpengaruh kecemasan istri menghadapi suami yang dirawat inap di RSUD Dr. Pirngadi Medan Tahun 2020, dapat dilihat pada tabel dibawah ini:

Tabel 2. Analisis Faktor yang Berpengaruh Kecemasan Istri Menghadapi Suami Yang Dirawat Inap di RSUD Dr. Pirngadi Medan Tahun 2020

\begin{tabular}{|c|c|c|c|c|c|c|c|c|c|}
\hline \multirow{3}{*}{ Biaya Berobat } & \multicolumn{6}{|c|}{ Kecemasan Istri } & \multirow{2}{*}{ OR } & \multirow{2}{*}{$95 \% \mathrm{Cl}$} & \multirow{2}{*}{ P value } \\
\hline & \multicolumn{2}{|c|}{ Ringan } & \multicolumn{2}{|c|}{ Berat } & \multicolumn{2}{|c|}{ Total } & & & \\
\hline & $\mathbf{n}$ & $\%$ & $\mathbf{n}$ & $\%$ & $\mathbf{N}$ & $\%$ & & 4,687- & \\
\hline Dibantu & 22 & 66,67 & 11 & 33,33 & 33 & 100 & 13,7 & 40,127 & ก \\
\hline Tidak dibantu & 7 & 12,72 & 48 & 87,28 & 55 & 100 & & & 0,000 \\
\hline Total & 29 & 32,95 & 59 & 67,05 & 88 & 100 & & & \\
\hline
\end{tabular}




\begin{tabular}{|c|c|c|c|c|c|c|c|c|c|}
\hline \multirow{3}{*}{$\begin{array}{l}\text { Beresiko } \\
\text { Kehilangan Orang } \\
\text { yang Dicintai }\end{array}$} & \multicolumn{6}{|c|}{ Kecemasan Istri } & \multirow{3}{*}{ OR } & \multirow{3}{*}{$95 \% \mathrm{Cl}$} & \multirow{3}{*}{$\mathrm{P}$ value } \\
\hline & \multicolumn{2}{|c|}{ Ringan } & \multicolumn{2}{|c|}{ Berat } & \multicolumn{2}{|c|}{ Total } & & & \\
\hline & $\mathbf{n}$ & $\%$ & $\mathbf{n}$ & $\%$ & $\mathbf{N}$ & $\%$ & & & \\
\hline Tidak berisiko & 19 & 76,00 & 6 & 24,00 & 25 & 0 & \multirow[t]{3}{*}{$\begin{array}{l}16,7 \\
83\end{array}$} & \multirow{3}{*}{$\begin{array}{l}5,369- \\
52,465\end{array}$} & \multirow{3}{*}{0,000} \\
\hline Berisiko & 10 & 15,87 & 53 & 60,23 & 63 & 00 & & & \\
\hline \multirow[t]{2}{*}{ Total } & 29 & 32,95 & 59 & 67,05 & 88 & 00 & & & \\
\hline & \multicolumn{6}{|c|}{ Kecemasan Istri } & & $95 \%$ & $P$ value \\
\hline \multirow[t]{2}{*}{ Kesembuhan } & \multicolumn{2}{|c|}{ Ringan } & \multicolumn{2}{|c|}{ Berat } & \multicolumn{2}{|c|}{ Total } & OR & $\mathrm{Cl}$ & P value \\
\hline & $\mathrm{n}$ & $\%$ & $n$ & $\%$ & $\mathrm{n}$ & $\%$ & & $0,561-$ & \\
\hline Tidak takut & 29 & 34,52 & 55 & 65,48 & 84 & 100 & 0,655 & 0,765 & \\
\hline Takut & 0 & 0 & 4 & 100 & 4 & 100 & & & 0,151 \\
\hline Total & 29 & 32,95 & 59 & 67,05 & 88 & 100 & & & \\
\hline
\end{tabular}

Berdasarkan tabel 2 diketahui bahwa dari 88 responden yang diteliti, sebagian besar responden mengatakan bahwa biaya berobat tidak dibantu sebanyak 55 (62,50\%) responden. Dari $55(62,50 \%)$ responden tersebut, ada sebanyak $7(12,72 \%)$ responden mengatakan bahwa biaya berobat tidak dibantu dan mengalami kecemasan kategori ringan, sebanyak $48 \quad(87,28 \%)$ responden mengatakan bahwa biaya berobat tidak dibantu dan mengalami kecemasan berat.

Berdasarkan hasil perhitungan di atas diketahui bahwa hasil uji statistik diperoleh nilai pada baris OR yaitu 13,714 (95\% $\mathrm{Cl}$ : $4,687-$ $40,127)$ yang artinya responden yang biaya berobat tidak dibantu kemungkinan 13,714 kali mengalami kecemasan berat daripada responden yang biaya berobat dibantu. Nilai $p$ significancy yaitu $0,000<0,05$. Sehingga dapat disimpulkan bahwa ada hubungan faktor biaya berobat dengan kecemasan istri menghadapi suami yang dirawat inap di RSUD Dr. Pirngadi Medan Tahun 2020.

Diketahui bahwa dari 88 responden yang diteliti, sebagian besar responden mengatakan bahwa berisiko kehilangan orang yang dicintai sebanyak $63(71,59 \%)$ responden. Dari 63 $(71,59 \%)$ responden tersebut, ada sebanyak $10(15,87 \%)$ responden mengatakan bahwa berisiko kehilangan orang yang dicintai dan mengalami kecemasan kategori ringan, sebanyak $53(60,23 \%)$ responden mengatakan bahwa berisiko kehilangan orang yang dicintai dan mengalami kecemasan berat.

Berdasarkan hasil perhitungan di atas diketahui bahwa hasil uji statistik diperoleh nilai pada baris OR yaitu 16,783 (95\% Cl: 5,369$52,465)$ yang artinya responden yang biaya berobat tidak dibantu kemungkinan 16,783 kali mengalami kecemasan berat daripada responden yang biaya berobat dibantu. Nilai $p$ significancy yaitu $0,000<0,05$. Sehingga dapat disimpulkan bahwa ada hubungan faktor beresiko kehilangan orang yang dicintai dengan kecemasan istri menghadapi suami yang dirawat inap di RSUD Dr. Pirngadi Medan Tahun 2020.

Diketahui bahwa dari 88 responden yang diteliti, sebagian besar responden mengatakan bahwa tidak takut sebanyak 84 (95,45\%) responden. Dari 84 (95,45\%) responden tersebut, ada sebanyak 29 (34,52\%) responden mengatakan bahwa tidak takut dan mengalami kecemasan kategori ringan, sebanyak $55(65,48 \%)$ responden mengatakan bahwa tidak takut dan mengalami kecemasan berat.

Berdasarkan hasil perhitungan di atas diketahui bahwa hasil uji statistik diperoleh nilai pada baris OR yaitu 0,655 $(95 \% \mathrm{Cl}$ : 0,561 $0,765)$ yang artinya responden yang tidak takut kemungkinan 0,655 kali mengalami kecemasan berat daripada responden yang takut. Nilai $p$ significancy yaitu 0,151<0,05. Sehingga dapat disimpulkan bahwa ada hubungan faktor kesembuhan dengan kecemasan istri menghadapi suami yang dirawat inap di RSUD Dr. Pirngadi Medan Tahun 2020.

\section{PEMBAHASAN}

Status ekonomi keluarga merupakan suatu komponen kelas sosial yang menunjukkan tingkat, dan sumber penghasilan keluarga serta gambaran keadaan keluarga dimana keluarga merupakan komponen dasar yang dapat menentukan derajat kelas ekonomi, yang terdiri dari kelas atas, menengah, dan kelas bawah. Sosial ekonomi yang rendah menjadi salah satu dari faktor prognosis buruk yang dapat memicu kecemasan seseorang dalam menghadapi anggota keluarganya yang sedang di rawat inap.

Berdasarkan hasil penelitian diketahui bahwa dari 88 responden yang diteliti, sebagian besar responden mengatakan bahwa 
biaya berobat tidak dibantu sebanyak 55 $(62,50 \%)$ responden. Dari $55 \quad(62,50 \%)$ responden tersebut, ada sebanyak 7 (12,72\%) responden mengatakan bahwa biaya berobat tidak dibantu dan mengalami kecemasan kategori ringan, sebanyak $48 \quad(87,28 \%)$ responden mengatakan bahwa biaya berobat tidak dibantu dan mengalami kecemasan berat.

Berdasarkan hasil perhitungan di atas diketahui bahwa hasil uji statistik diperoleh nilai p significancy yaitu $0,000<0,05$. Sehingga dapat disimpulkan bahwa ada hubungan faktor biaya berobat dengan kecemasan istri menghadapi suami yang dirawat inap di RSUD Dr. Pirngadi Medan Tahun 2020.

Dukungan sikap empati dari anggota keluarga lainnya juga sangat diharapkan keluarga selama mendampingi pasien yang di rawat inap pada fase end of life. Bentuk empati yang ditunjukkan yakni melalui perhatian seperti sikap saling pengertian, turut membantu biaya pengobatan, ikut menjaga pasien yang di rawat inap di rumah sakit, mengantar dan menjemput anggota keluarga yang akan gantian menjaga.

Dalam berbagai hasil penelitian diungkapkan bahwa pemberian dukungan dari anggota keluarga lainnya juga sangat diharapkan oleh keluarga selama mendampingi pasien yang di rawat inap pada fase end of life. Dukungan yang diharapkan yakni turut mengunjungi selama di rumah sakit, sebagai tempat konsultasi, menyediakan transportasi, membantu tugas-tugas rumah tangga dan memberikan pengertian kepada anak-anak. Dengan demikan anggota keluarga lainnya sudah menunjukkan empatinya kepada keluarga yang mendampingi pasien yang di rawat inap pada fase end of life

Hambatan yang dialami keluarga selama mendampingi pasien yang di rawat inap pada fase end of life yakni kompleksitas tanggung jawab keluarga selama mendampingi dan membiayai pengobatan. Tanggung jawab yang harus dilaksanakan oleh keluarga selain mendampingi pasien yang di rawat inap di rumah sakit juga harus mengatur banyak hal, seperti mengumpulkan saudara, mengurus rumah tangganya sendiri dan menggantikan peran dari pasien yang di rawat inap tersebut. Dengan adanya banyak tanggung jawab yang harus dilaksanakan membuat keluarga sudah mulai merasakan kelelahan dan kondisi fisiknya sudah mulai menurun.

Menurut Efendy, et.al.(2014) dalam penelitiannya mengungkapkan bahwa hambatan yang dialami keluarga selama mendampingi pasien yang di rawat inap pada fase end of life seperti tanggung jawab terhadap pekerjaan rumah tangga. Hal ini menyebabkan keluarga harus mengatur ulang tugas dan kewajiban yang biasa mereka lakukan, misalnya kegiatan rumah tangga sendiri, selain itu juga merawat orang lain yang bergantung pada mereka seperti anak-anak. ${ }^{12}$

Kesulitan lainnya yang menjadi hambatan bagi keluarga yakni tidak mampu dalam memenuhi biaya pengobatan. Keluarga cukup dilema karena disatu sisi mereka ingin agar pasien yang di rawat inap mendapatkan pengobatan dan perawatan yang baik tetapi disisi lainnya mereka harus dihadapkan dengan biaya pengobatan yang dirasakan sangatmahal. Perubahan kondisi ini dirasakan keluarga sebagai sebuah hambatan selama mendampingi pasien yang di rawat inap .

Kecemasan merupakan bagian normal dari kehidupan sehari-hari. Namun, perlu diwaspadai bila terus menerus merasa cemas. Sebab, bisa jadi mengalami gangguan kecemasan atau anxiety disorder. Ketika seseorang merasa cemas, hormon-hormon stres seperti kortisol dan adrenalin dilepaskan yang dapat berdampak pada bagian tubuh yang lain. Hal ini menempatkan tubuh dalam mode fight or flight.

Kortisol (hormon steroid yang diproduksi oleh kolesterol di dalam dua kelenjar adrenal yang terdapat pada tiap ginjal) mencegah pelepasan zat-zat yang menyebabkan peradangan, dan mematikan aspek-aspek sistem kekebalan yang melawan infeksi, kemudian merusak respons kekebalan alami tubuh. Kecemasan, kekhawatiran, kepanikan, ketakutan, kegelisahan merupakan gejala psikologis yang umum dan dapat dirasakan oleh setiap individu. Reaksi kecemasan biasanya sering terjadi pada orang dewasa, namun anak-anak juga dapat menghadapi rasa cemas, seperti ditinggalkan

Berdasarkan hasil penelitian, diketahui bahwa dari 88 responden yang diteliti, sebagian besar responden mengatakan bahwa berisiko kehilangan orang yang dicintai sebanyak $63(71,59 \%)$ responden. Dari 63 $(71,59 \%)$ responden tersebut, ada sebanyak $10(15,87 \%)$ responden mengatakan bahwa berisiko kehilangan orang yang dicintai dan mengalami kecemasan kategori ringan, sebanyak $53(60,23 \%)$ responden mengatakan bahwa berisiko kehilangan orang yang dicintai dan mengalami kecemasan berat.

Berdasarkan hasil perhitungan di atas diketahui bahwa hasil uji statistik diperoleh nilai pada baris OR yaitu 16,783 (95\% Cl: 5,369$52,465)$ yang artinya responden yang biaya berobat tidak dibantu kemungkinan 16,783 kali mengalami kecemasan berat daripada responden yang biaya berobat dibantu. Nilai $p$ 
significancy yaitu $0,000<0,05$. Sehingga dapat disimpulkan bahwa ada pengaruh faktor beresiko kehilangan orang yang dicintai terhadap kecemasan istri menghadapi suami yang dirawat inap di RSUD Dr. Pirngadi Medan Tahun 2020.

Keluarga yang mendampingi pasien yang di rawat inap pada fase end of lifeakan mengalami kecemasan yang disebabkan selalu berpikiran negatif tentang kondisi pasien yang di rawat inap yang dimulai saat mendengar diagnosis medis yang terus berubah, melihat perubahan kondisi yang berbeda dari sebelumnya dan mempunyai anggapan bahwa penyakit yang dialami pasien yang di rawat inap dapat membuat pasien yang di rawat inap tersebut tidak dapat terselamatkan.

Selama mendampingi pasien yang di rawat inap dan melihat perubahan kondisi pasien yang di rawat inap yang tidak kunjung membaik, membuat keluarga memiliki perasaan takut kehilangan orang yang dicintai. Oleh karena itu, keluarga berupaya untuk memastikan bahwa pasien yang di rawat inap mendapat perawatan yang baik, menyemangati pasien yang di rawat inap dengan berbagai cara dan menampung pilihan lain selain pengobatan medis. Ditengah rasa cemas yang dirasakan, keluarga butuh disemangati oleh petugas kesehatan dan adanya dukungan sikap empati dari anggota keluarga lainnya.

Keluarga juga mengalami hambatan selamamendampingi pasien yang di rawat inap yakni adanya kompleksitas tanggung jawab keluarga dalam mendampingi dan membiayai pengobatan. Saran yang dapat diberikan dari penelitian ini ditujukan pada keluarga, perawat dan peneliti selanjutnya. Bagi keluarga, peneliti menyarankan agar dapat menggunakan support systemyang sudah ada baik yang berasal dari anggota keluarga lainnya maupun petugas kesehatan sebagai sumber kekuatan untuk mengatasi kecemasan.

Kehilangan adalah suatu keadaan dimana individu berpisah dengan sesuatu yang sebelumnya ada menjadi tidak ada, baik itu secara sebagian atau keseluruhan. Kehilangan merupakan pengalaman yang pernah dialami oleh setiap manusia selama rentang kehidupannya, sejak lahir manusia sudah mengalami kehilangan dan cenderung akan mengalaminya kembali walaupun dalam bentuk yang berbeda. Sehingga bisa disimpulkan bahwa kehilangan merupakan suatu gangguan jiwa yang biasa terjadi pada individu-individu yang menghadapi suatu keadaan yang berubah dari keadaan semula (keadaan yang sebelumya ada menjadi tidak ada). Kehilangan dan kematian adalah suatu peristiwa dari pengalaman hidup manusia yang bersifat universal dan unik secara individu. ${ }^{13}$

Perasaan cemas yang dihadapi dan dialami oleh salah satu anggota keluargamempengaruhi seluruh keluarga. Kecemasan dapat timbul secara otomatis akibat dari stimulus internal dan eksternal yang berlebihan sehingga melampaui kemampuan individu untuk menanganinya maka timbul cemas. ${ }^{14}$ Keluarga merupakan unit yang paling dekat dengan pasien dan perawat mempunyai peranan utama bagi pasien dan keluargadalam memberikan dukungan moral terhadap kesembuhan pasien. ${ }^{15}$ Dalam kondisi cemas dan stres keluarga akan membutuhkan waktu lama untuk pengambilan keputusan, sehingga dapat mempengaruhi dan menunda pemberian tindakan yang bersifat segera untuk pasien.

Berdasarkan hasil penelitian diketahui bahwa dari dari 88 responden yang diteliti, sebagian besar responden mengatakan bahwa tidak takut sebanyak $84(95,45 \%)$ responden. Dari $84(95,45 \%)$ responden tersebut, ada sebanyak $29(34,52 \%)$ responden mengatakan bahwa tidak takut dan mengalami kecemasan kategori ringan, sebanyak $55 \quad(65,48 \%)$ responden mengatakan bahwa tidak takut dan mengalami kecemasan berat.

Berdasarkan hasil perhitungan di atas diketahui bahwa hasil uji statistik diperoleh nilai p significancy yaitu 0,151<0,05. Sehingga dapat disimpulkan bahwa tidak ada hubungan faktor kesembuhan dengan kecemasan istri menghadapi suami yang dirawat inap di RSUD Dr. Pirngadi Medan Tahun 2020.

Konsep sembuh dapat didasarkan pembagiannya pada sembuh fisik, sembuh psikis dan sembuh secara sosial.Secara umum kondisi umum diklasifikasikan ke dalam 4 macam, yaitu sembuh sempurna, sembuh dengan cacat, sembuh dengan pembawa, dan meninggal dunia. Sembuh dengan sempurna yaitu kondisi dimana fungsi tubuh menjadi pulih seperti sebelumnya atau kembali dalam keadaan semula. Dalam kasus tertentu kesembuhan ini dapat berlangsung dengan tidak sempurna sehingga menimbulkan cacat. Keadaan inilah yang desebut sebagai sembuh dengan cacat. Keadaan lain dapat berupa sembuh dengan membawa sedikit bibit penyakit, artinya meskipun pasien sudah merasa sembuh, akan tetapi masih ada bibit penyakit yang suatu saat nanti akan menimbulkan penyakit lagi. Klasifikasi terakhir yaitu meninggal dunia. Meninggal dunia merupakan akhir perjalanan suatu penyakit yang pada hakikatnya dengan meninggalnya seseorang berarti perkembangan penyakit juga ikut terhenti. Uraian tersebut merupakan 
konsep sembuh berdasarkan medis yang selama ini diketahui masyarakat umum.

Namun, dalam Antropologi kesehatan sembuh dapat dilihat dari segi sosial, psikis, dan fisik (medis). Menurut Sorensen, sembuh secara sosial berkaitan dengan penerimaan oleh masyarakat sekitar dimana seseorang hidup. Sehat secara psikis orang dikatakan sembuh ketika dia menjadi pendengar yang baik bagi orang yang berada di sekelilingnya. Sedangkan sembuh secara medis adalah kondisi yang didasarkan atas pengukuran/standar yang pasti berupa diagnosa dan uji laboratorium yang menggunakan alat-alat medis modern. ${ }^{16}$

\section{KESIMPULAN DAN SARAN}

Berdasarkan hasil penelitian yang telah dilakukan oleh peneliti maka penelitian ini menghasilkan kesimpulan bahwa faktor biaya berobat, faktor beresiko kehilangan orang yang dicintai, faktor kesembuhan, faktor siapa yang menjaga, faktor urusan rumah tangga, faktor ancaman nafkah keluarga, dan faktor lama rawat inap berpengaruh terhadap kecemasan istri menghadapi suami yang dirawat inap di RSUD DR. Pirngadi Medan Tahun 2020 dan faktor yang paling berhubungan adalah faktor beresiko kehilangan orang yang dicintai. Maka disarankan saran agar istri dapat meningkatkan keimanan supaya bersabar menghadapi suami yang dirawat inap dan dapat lebihkan meningkatkan kepercayaan atau keyakinan terhadap pelayanan rumah sakit untuk kesembuhan suami yang dirawat.

\section{DAFTAR PUSTAKA}

1. Mohamad Abdul Azis. Peran Suami Dalam Membentuk Keluarga Sakinah (Studi Kasus Dua Keluarga Di Padukuhan Papringan, Caturtunggal, Depok, Sleman, Yogyakarta). 2015;8:1-27.

2. Putri DPK, Lestari S. Pembagian Peran Dalam Rumah Tangga Pada Pasangan Suami Istri Jawa. J Penelit Hum. 2015;16(1):72-85.

3. IImi YS. Peran Pemimpin Keluarga Dalam Pengambilan Keputusan. Semin Nas Psikol Indig Indones 2016. 2016;301-7.

4. Savitri Ramaiah. Kecemasan Bagaimana Mengatasi Penyebabnya. Jakarta: Pustaka Populer Obor.; 2003

5. Sutardjo Wiramihardja. PengantarPsikologi Abnormal.Bandung: Refika Aditama; 2005

6. Donner, Nina C\&Lowry, Christoper A. Sex Differences in Anxiety and Emotional Behavior. Pflugers Arch -Eur J Physiol 465, 601-626;2013
7. Kemenkes Ri. 2013.Riset Kesehatan Dasar; RISKESDAS. Jakarta:BalitbangKemenkes Ri

8. Indrayani A, Santoso A. Hubungan Pendidikan Kesehatan Dengan Kecemasan Orang Tua Pada Anak Hospitalisasi. Diponegoro J Nurs. 2012;1(1):163-8.

9. Astutik W, Kuswati E. Efektivitas Pemberian Jus Kulit Manggis Terhadap Kadar Hormon Kortisol Pada Mencit (Mus musculus) Yang Mengalami Stres. J Skala Husada. 2014;11(1):91-5.

10. Mimatun Nasihah Ninis Nur Hidayah. Pengaruh Peran Serta Suami Terhadap Tingkat Kecemasan Ibu Hamil Dalam Menghadapi Proses Persalinan Di Desa Tejosari Kecamatan Laren Kabupaten Lamongan 2015. 2015;

11. Kaplan, H.I., Sadock, B.J. Buku Ajar Psikiatri Klinis. Edisi ke 2.. Penerjemah : Husny Muttaqin.. Jakarta : EGC.; 2010

12. Effendy, Onong Uchyana. (2014). IImu Komunikasi: Teori dan Prakteknya, Bandung : Remaja Rosdakarya.

13. Sumadi Suryabrata. Psikologi Kepribadian. Cetakan ke 4. Jakarta: Raja Grafindo Pustaka; 2001

14. Stuart G. W \& Sundeen S. J. Buku saku keperawatan jiwa (edisi 3), Alih bahasa, Achir Yani, Editor Yasmin Asih, EGC, Jakarta; 2006

15. Yosep I. KeperawatanJiwa. Bandung: RefikaAditama;2007

16. Townsend, B.A. Keperawatan dengan Gangguan Harga Diri. Jakarta: Trans Info Medika; 2005 